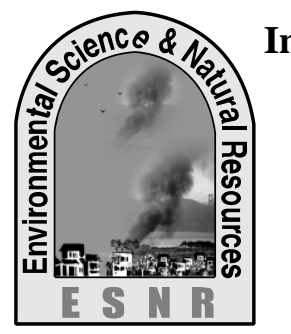

\title{
Investigation of Water Quality Parameters at Different Points in the Buriganga River, Bangladesh
}

\author{
M. A. Akbor ${ }^{1}$, M. K. Uddin ${ }^{2 *}$ and M. A. Ahsan ${ }^{1}$ \\ ${ }^{1}$ Institute of National Analytical Research and Service (INARS), BCSIR, Dhaka, Bangladesh, \\ ${ }^{2}$ Department of Environmental Sciences, Jahangirnagar University, Savar, Dhaka- 1342 \\ *Corresponding author: khabir88@yahoo.com
}

\begin{abstract}
Dhaka was established as a provincial capital of the Mughal ruler on the north-eastern bank of the Buriganga River during 1608-10. This river has enormous significance to the residents of Dhaka. Not only it surrounds the city, but also it provides important services to the residents including water supply, navigation, recreation, sanitation, fish production, tourism, biodiversity and flood control. A study was carried out to observe the ecological health hazards and their risk to human health of the Buriganga River. The samples were analyzed to determine water quality. The study showed that the water is high in biological oxygen demand (BOD), chemical oxygen demand (COD), Electrical conductivity (EC), Total dissolved solid (TDS), Salinity, Alkalinity, Turbidity and low in dissolved oxygen (DO) which revealed huge environmental health risks and possible ecological disruption of this river.
\end{abstract}

Key words: Biological oxygen demand, Chemical oxygen demand, Dissolved oxygen, Electrical conductivity and Reduction potential

\section{Introduction}

Development activities and utilization of the river create a great threat to the existing natural environmental system, particularly for Buriganga River which flow besides Dhaka, capital of Bangladesh, due to the pollution of the river water. Buriganga is very important River in respect of communication and source of drinking water. But continuously polluted in different way. River Buriganga, which runs past Dhaka City, is currently one of the most polluted bodies of water in Bangladesh. Different industries are discharging their solid wastes and liquid effluent containing putrid rotten flesh, fat, blood and skin, toxic chemicals, dissolved lime, chromium sulfate, alkali, hydrogen sulfide, sulfuric acid, bleach dyes, oil formic acid, heavy metals, suspended solids, organic matters, etc., directly into low-lying areas and water bodies without proper treatment. Modern civilization creates an environment to meet human aspirations which result in constant improvements of our lifestyle, but it also increases risks to human and ecological health. This situation motivated throughout the world to analyze the environmental factors that can affect our health, ecology and to calculate the levels of risk. Climate change, water pollution, air pollution etc. which are after effect of industrialized civilization. To get a vivid scenario water pollution of a river $\&$ its effect on the environment as well as human, the Ecological Health Risk of the Buriganga River of Dhaka, Bangladesh has been identified as the study problem. The problems related to Buriganga can be categorized as natural, climate change-related, external to the country, and human made (Alam, 1995). The source of the surface water of the city and about $18 \%$ of the supplied by Dhaka WASA is surface water (Rahman, 2004). But the surface water systems of this city at present time are polluted by various ways (Islam, 2009). The sources of surface water pollution are mainly from agricultural, industrial and domestic wastes (De, 2000; Dara, 2002). Pollution from human and industrial sources is the main water quality problem in the river systems near urban areas because they are one of the largest water users and polluters (Nemerow, 1978). Buriganga is the worst affected. The careless disposal of industrial effluents and other wastes may contribute greatly to the poor quality of the water (Chindah et al., 2004). Anthropogenic activities, as well as the variation in river water flow during different seasons were the main reasons for this high degree of water pollution (Islam et al., 2015).

Local people are dependent on this river for their livelihoods but they are not aware of pollution of the river water in this area. So, it is needed to know the water quality status of this river. Keeping these points in thinking, the proposed research project will focus on determining the water quality parameters at different point of Buriganga and its effects. It will also identify the basic characteristics of water at different points and develop public awareness and help in formulating guidelines regarding this problem.

\section{Materials and Methods}

Water samples were collected in eight selected ghats (points) which aresadarghat gate no; 1shwiseghat gate no; 2, mosque ghat, steamer ghat, rocket ghat, six no ghat, babu bazaar ghat, midfortghat, in the river of Buriganga. The study was carried out from January to March 2016. The sampling was done very cautiously using spot sampling techniques (Gupta, 2005). The high density PVC bottles were used for sampling. They were thoroughly cleaned by rinsing with $10 \% \mathrm{HNO}_{3}$ and deionized water followed by repeated washing with water samples so as to avoid contamination (De, 2000). Aeration during sampling was avoided as best as possible. The $\mathrm{pH}$, dissolved oxygen (DO), electrical conductivity (EC), total dissolved solids (TDS), Salinity, Redox-potential (RP), values of water samples were measured by a Sension 156TM Multi-parameter (APHA, 1998). Biological Oxygen Demand (BOD) was measured by following 5 days incubation method. Distilled water was taken in volumetric flasks. Then aerated air was passed in the flask by an air compressor. 
The aerated water was transferred into volumetric flask and the beaker was filled with distilled water up to the mark. Then the dissolved oxygen (DO) content of collected water sample was measured by using DO meter. Then the bottle was kept in an incubator for 5 days. After incubation, the dissolved oxygen was measured again by using DO meter. The difference of two DO values was calculated for each sample and it was the BOD value (APHA, 1998). Alkalinity, Hardness, Acidity, Free carbon dioxide was measured by titrimetric method. Turbidity was measured by Turbidity meter.

\section{Results and Discussion}

Dissolved oxygen (DO), Temperature, Electrical Conductivity/Salinity, COD, BOD are very important aquatic systems. Impairments of these can be observed as impacts to the flora and or fauna with a given water body.

Table 1. Water quality parameters

\begin{tabular}{|c|c|c|c|c|c|c|c|c|c|}
\hline $\begin{array}{l}\text { Name of } \\
\text { the points }\end{array}$ & $\begin{array}{l}\text { Sadarghat } \\
\text { gate no; } 1\end{array}$ & $\begin{array}{l}\text { Shwiseghat } \\
\text { gate no;2 }\end{array}$ & $\begin{array}{l}\text { Mosque } \\
\text { ghat }\end{array}$ & $\begin{array}{l}\text { Steamer } \\
\text { ghat }\end{array}$ & $\begin{array}{l}\text { Rocket } \\
\text { ghat }\end{array}$ & $\begin{array}{l}\text { Six no } \\
\text { ghat }\end{array}$ & $\begin{array}{l}\text { Babu } \\
\text { bazaar } \\
\text { ghat }\end{array}$ & Midfort ghat & $\begin{array}{ll}\text { Std of } \\
\text { DoE }\end{array}$ \\
\hline $\mathrm{EC} \mu \mathrm{S} / \mathrm{cm}$ & 1190 & 1189 & 1177 & 1224 & 1360 & 1187 & 1171 & 1173 & 1200 \\
\hline TDS mg/L & 587 & 586 & 580 & 604 & 673 & 585 & 577 & 578 & 2100 \\
\hline Sal ppt & 0.6 & 0.6 & 0.5 & 0.6 & 0.6 & 0.6 & 0.5 & 0.5 & \\
\hline $\mathrm{pH}$ & 6.99 & 7.28 & 7.8 & 7.09 & 6.82 & 7.7 & 7.44 & 7.37 & $6-9$ \\
\hline $\mathrm{RP}, \mathrm{mv}$ & 6.1 & -11.4 & -40.6 & -0.6 & -14.1 & -7.9 & -14.2 & -10.7 & \\
\hline $\mathrm{DO}, \mathrm{mg} / \mathrm{L}$ & 3.05 & 4.35 & 6.13 & 6 & 0.43 & 4.65 & 4.44 & 2.97 & $4.5-8$ \\
\hline $\begin{array}{l}\mathrm{BOD} \\
\mathrm{mg} / \mathrm{L}\end{array}$ & 88.25 & 24.8 & 12.3 & 14.7 & 248 & 20.2 & 9.15 & 37.5 & 50 \\
\hline $\begin{array}{l}\text { COD, } \\
\mathrm{mg} / \mathrm{L}\end{array}$ & 218 & 54.88 & 27.44 & 32.34 & 509 & 45.08 & 19.6 & 76.44 & 200 \\
\hline $\begin{array}{l}\text { Hardness, } \\
\mathrm{mg} / \mathrm{L}\end{array}$ & 81.7 & 76.2 & 79.5 & 71.3 & 155 & 181 & 170 & 188 & 300 \\
\hline $\begin{array}{l}\text { Acidity, } \\
\mathrm{mg} / \mathrm{L}\end{array}$ & 9.98 & 17.2 & 26.4 & 22.1 & 19.2 & 37.5 & 26.1 & 43.13 & \\
\hline $\begin{array}{l}\text { Free } \mathrm{CO}_{2}, \\
\mathrm{mg} / \mathrm{L}\end{array}$ & 8.78 & 13.8 & 24.4 & 19.4 & 16.5 & 35.6 & 22.3 & 37.95 & 10 \\
\hline $\begin{array}{l}\text { Alkalinity, } \\
\mathrm{mg} / \mathrm{L}\end{array}$ & 270 & 210 & 250 & 195 & 260 & 265 & 180 & 223 & 200 \\
\hline $\begin{array}{l}\text { Turbidity, } \\
\text { NTU }\end{array}$ & 216 & 21.4 & 53.5 & 57.5 & 80.2 & 11.8 & 15.7 & 14.9 & 20 \\
\hline
\end{tabular}

\section{Dissolved Oxygen}

It is the amount of oxygen dissolved in water. Most aquatic organisms need oxygen to survive and grow. Some species require high DO such as trout and stoneflies. Other species do not require high DO, like catfish, worms and dragonflies.

If there is not enough oxygen in the water the following may happen: - Death of adults and juveniles, Reduction in growth, $\bullet$ Failure of eggs/larvae to survive, - Change of species present in a given water body. The average, maximum and minimum DO values of all collected samples were $4.0 \mathrm{mg} / \mathrm{L}, 6.13 \mathrm{mg} / \mathrm{L}$ and 0.43 $\mathrm{mg} / \mathrm{L}$ respectively (Table 1 ). The optimum $\mathrm{DO}$ in natural water is 4 to $6 \mathrm{mg} / \mathrm{L}$ (De, 2005). According to Ganeshalingam et al. (2012), found DO of pond water ranged from 6.06 to $10.99 \mathrm{mg} / \mathrm{L}$. The $\mathrm{DO}$ of all collected water samples were varied between 0.43 to $6.13 \mathrm{mg} / \mathrm{L}$ which all were not suitable for aquaculture DO is essential for sustaining the plant and animal life in aquatic system. Warm water fish requires a minimum
DO level, at least $5 \mathrm{mg} / \mathrm{l}$. The minimum amount of DO is $5 \mathrm{mg} \mathrm{l}^{-1}$ for survival aquatic animals and level <4 $\mathrm{mg} / \mathrm{l}$ causes killing of fish and other animals of water kingdom.

Reduction potential (also known as redox potential, oxidation / reduction potential, ORP,) is a measure of the tendency of a chemical species to acquire electrons and thereby be reduced. Reduction potential is measured in volts $(\mathrm{V})$, or millivolts $(\mathrm{mV})$. Each species has its own intrinsic reduction potential. A solution with a higher (more positive) reduction potential than the new species will have a tendency to gain electrons from the new species (i.e. to be reduced by oxidizing the new species) and a solution with a lower (more negative) reduction potential will have a tendency to lose electrons to the new species (i.e. to be oxidized by reducing the new species).The average, maximum and minimum RP values of all collected samples were (-)11.1 mv, $6.1 \mathrm{mv}$ and (-) 40.6 respectively (Table 1). 
Table 2. Mean, median, minimum and maximum values of Water quality parameters

\begin{tabular}{|c|c|c|c|c|c|}
\hline \multirow{2}{*}{$\mathrm{EC}, \mu \mathrm{S} / \mathrm{cm}$} & Mean & Standard Error & Median & Minimum & Maximum \\
\hline & 1208.875 & 22.37460095 & 1188 & 1171 & 1360 \\
\hline \multirow{2}{*}{$\mathrm{TDS}, \mathrm{mg} / \mathrm{L}$} & Mean & Standard Error & Median & Minimum & Maximum \\
\hline & 596.25 & 11.36685344 & 585.5 & 577 & 673 \\
\hline \multirow{2}{*}{ Sal, ppt } & Mean & Standard Error & Median & Minimum & Maximum \\
\hline & 0.5625 & 0.018298126 & 0.6 & 0.5 & 0.6 \\
\hline \multirow{2}{*}{$\mathrm{pH}$} & Mean & Standard Error & Median & Minimum & Maximum \\
\hline & 7.31125 & 0.119857616 & 7.325 & 6.82 & 7.8 \\
\hline \multirow{2}{*}{$\mathrm{RP}, \mathrm{mv}$} & Mean & Standard Error & Median & Minimum & Maximum \\
\hline & $(-) 11.675$ & 4.82 & $(-) 11.1$ & $(-) 40.6$ & 6.1 \\
\hline \multirow{2}{*}{$\mathrm{DO}, \mathrm{mg} / \mathrm{L}$} & Mean & Standard Error & Median & Minimum & Maximum \\
\hline & 4.0025 & 0.654432006 & 4.395 & 0.43 & 6.13 \\
\hline \multirow{2}{*}{$\mathrm{BOD}, \mathrm{mg} / \mathrm{L}$} & Mean & Standard Error & Median & Minimum & Maximum \\
\hline & 56.8625 & 28.7556652 & 22.5 & 9.15 & 248 \\
\hline \multirow{2}{*}{$\mathrm{COD}, \mathrm{mg} / \mathrm{L}$} & Mean & Standard Error & Median & Minimum & Maximum \\
\hline & 122.8475 & 59.60330431 & 49.98 & 19.6 & 509 \\
\hline \multirow{2}{*}{ Hardness, mg/L } & Mean & Standard Error & Median & Minimum & Maximum \\
\hline & 125.3375 & 18.53537099 & 118.35 & 71.3 & 188 \\
\hline \multirow{2}{*}{ Acidity, mg/L } & Mean & Standard Error & Median & Minimum & Maximum \\
\hline & 25.20125 & 3.817916615 & 24.1 & 9.98 & 43.13 \\
\hline \multirow{2}{*}{ Free $\mathrm{CO} 2, \mathrm{mg} / \mathrm{L}$} & Mean & Standard Error & Median & Minimum & Maximum \\
\hline & 22.34125 & 3.593891861 & 20.85 & 8.78 & 37.95 \\
\hline \multirow{2}{*}{ Alkalinity, mg/L } & Mean & Standard Error & Median & Minimum & Maximum \\
\hline & 231.625 & 12.15809181 & 236.5 & 180 & 270 \\
\hline \multirow{2}{*}{ Turbidity, NTU } & Mean & Standard Error & Median & Minimum & Maximum \\
\hline & 58.875 & 24.12471873 & 37.45 & 11.8 & 216 \\
\hline
\end{tabular}

\section{Electrical Conductivity}

Solids can be found in nature in a dissolved form. Salts that dissolve in water break into positively and negatively charged ions. Conductivity is the ability of water to conduct an electrical current, and the dissolved ions are the conductors. The average, maximum and minimum EC values of all collected samples were $1208 \mu \mathrm{S} / \mathrm{cm}, 1360 \mu \mathrm{S} / \mathrm{cm}$ and $1171 \mu \mathrm{S} / \mathrm{cm}$ respectively (Table 1). The standard level of EC for fishing is 1000 $\mu \mathrm{S} / \mathrm{cm}$ (ADB, 1994), All collected samples were beyond the acceptable range. So, this river was not suitable for aquaculture.

\section{Salinity}

Salinity is a measure of the amount of salts in the water. Because dissolved ions increase salinity as well as conductivity, the two measures are related. The salts in sea water are primarily sodium chloride $(\mathrm{NaCl})$. However, other saline waters, such as Mono Lake, owe 
their high salinity to a combination of dissolved ions including sodium, chloride, carbonate and sulfate. The average, maximum and minimum salinity values of all collected samples were $0.562 \mathrm{ppt} 0.6 \mathrm{ppt}$ and $0.5 \mathrm{ppt}$ respectively (Table 1). Salinity is an important parameter for determining the water quality. More saline water is more alkaline and this causes harm and irreversible damage of the surrounding aquatic and plant life. The fresh water organisms cannot tolerate highly saline water. Fresh water becomes saline when industries dump large quantity saline substances into it. Salts are such type of electrolyte substances that contribute cationic and anionic species to the water except Hydrogen ion $\left(\mathrm{H}^{+}\right)$and hydroxyl ion $\left(\mathrm{OH}^{-}\right)$(Das, 1997). The salinity of water indicates the presence of ionic substances that may come from reaction of metals and acids containing in water.

\section{pH}

The average $\mathrm{pH}$ values were 7.31. The $\mathrm{pH}$ of all collected water samples were varied between 6.82 to 7.80 (Table 1). According to De (2005), the usual pH range for freshwater aquatic system is 6.5 to 8.5 with most waterways around 7 . As this diagram shows, $\mathrm{pH}$ ranges from 0 to 14, with 7 being neutral. pHs less than 7 are acidic while pHs greater than 7 are alkaline (basic). Normal rainfall has a pH of about 5.6-slightly acidic due to carbon dioxide gas from the atmosphere. Acid rain can be very acidic, and it can affect the environment in a negative way.

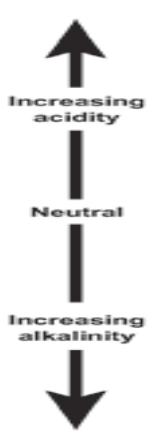

\section{Biological oxygen demand (BOD)}

Biochemical oxygen demand or BOD is the amount of dissolved oxygen needed by aerobic biological organisms in a body of water to break down organic material present in a given water sample at certain temperature over a specific time period. The average values of BOD of was $56.8 \mathrm{mg} / \mathrm{L}$ (Table 1). The BOD of all collected water samples were varied between 9.15 to 248. Chowdhury (2009) recommended that optimum BOD level for aquaculture should be less than $6 \mathrm{mg} / \mathrm{L}$. On the basis of measured BOD all water samples were beyond the acceptable range. So, from the observation of river, it is seen that the BOD level was not suitable for fish production and environment.

\section{Chemical oxygen demand (COD)}

Chemical oxygen demand (COD) test is commonly used to indirectly measure the amount of organic compounds in water. Most applications of COD determine the amount of organic pollutants found in surface water. It is expressed in milligrams per liter $(\mathrm{mg} / \mathrm{L})$, which indicates the mass of oxygen consumed per liter of solution. Older references may express the units as parts per million (ppm). The COD of all collected water samples were varied between 19.6 to 509 (Table 1) Chowdhury (2009) recommended that optimum COD level for aquaculture should be less than $200 \mathrm{mg} / \mathrm{L}$. On the basis of measured COD all water samples were not within the acceptable range. So, from the observation of river it is seen that the COD level was not suitable for fish production and environment.

\section{Total dissolved solids (TDS)}

TDS in water may responsible for occurring bad odor and taste and may promote conditions favorable for growth of pathogenic bacteria (Khabir et al., 2002). It is recommended that TDS in $\mathrm{mg} / \mathrm{l}$ should be around half of electrical conductivity in $\mu \mathrm{s} / \mathrm{cm}(\mathrm{HACH}, 1997$; Ahmed et al., 2007). If the TDS is higher than $1 / 2$ electrical conductivity $(\mu \mathrm{s} / \mathrm{cm})$, it indicates the considerable amount of dissolved organic matter may be present. The average value of TDS of was $596 \mathrm{mg} / \mathrm{L}$. The TDS of all collected water samples were varied between 577 to $673 \mathrm{mg} / \mathrm{L}$ (Table 1). According to DoE (2005), the standard value of TDS for freshwater is 500 $\mathrm{mg} / \mathrm{L}$. Measured TDS values of all samples collected from the study area was beyond the acceptable range. So, from the observation of river water it is seen that the TDS level was not suitable for fish production and environment.

\footnotetext{
Alkalinity

Alkalinity represents the buffering capacity of water and its ability to resist a change in $\mathrm{pH}$. Alken-Murray recommends alkalinity above $75 \mathrm{mg} / \mathrm{L}$ to offset acid produced by bacteria nitrifying ammonia. For fishing purpose maximum tolerable limit of alkalinity is 200 $\mathrm{mg} / \mathrm{L}$ (Mowka and Edmund, 1988). On this scale $\mathrm{p}^{\mathrm{H}}$ above 7 is alkaline. Higher alkalinities are associated with increased productivity along with increased growth of algae and aquatic plants. Many algaecides lose effectiveness in alkaline conditions making algae control more difficult. Alkalinity level of all collected water samples were varied between $223 \mathrm{mg} / \mathrm{L}$ to 270 $\mathrm{mg} / \mathrm{L}$ (Table 1). So, from the observation, it is seen that
} 
the alkalinity level was not suitable for fish production and environment.

\section{Carbon Di-oxide $\left(\mathrm{CO}_{2}\right)$}

Carbon Di-oxide is present in water in the form of a dissolved gas. Surface waters normally contain less than $10 \mathrm{ppm}$ free carbon dioxide, while some ground waters may easily exceed that concentration. Carbon dioxide is readily soluble in water. Over the ordinary temperature range $\left(0-30^{\circ} \mathrm{C}\right)$ the solubility is about 200 times that of oxygen. Calcium and magnesium combine with carbon dioxide to form carbonates and bicarbonates. Aquatic plant life depends upon carbon dioxide and bicarbonates in water for growth. Microscopic plant life suspended in the water, phytoplankton, as well as large rooted plants, utilize carbon dioxide in the photosynthesis of plant materials; starches, sugars, oils, proteins. The carbon in all these materials comes from the carbon dioxide in water. Carbon Di-oxide level of all collected water samples were varied between 8.78 $\mathrm{mg} / \mathrm{L}$ to $37.9 \mathrm{mg} / \mathrm{L}$ (Table 1 ), so, from the observation it is seen that the Carbon Di-oxide level was not suitable for fish production and environment.

\section{Hardness}

Water is considered soft if it contains 0 to $60 \mathrm{mg} / \mathrm{L}$ of hardness, moderately hard from 61 to $120 \mathrm{mg} / \mathrm{L}$, hard between 121 and $180 \mathrm{mg} / \mathrm{L}$, and very hard if more than $180 \mathrm{mg} / \mathrm{L}$. Very hard water is not desirable for many domestic uses; it will leave a scaly deposit on the inside of pipes, boilers, and tanks. Hard water can be softened at a fairly reasonable cost, but it is not always desirable to remove all the minerals that make water hard. Extremely soft water is likely to corrode metals, although it is preferred for laundering, dishwashing, and bathing. In fishing purpose maximum recommended range of hardness $300 \mathrm{mg} / \mathrm{l}$ (Mokwa and Edmand, 1998). Hardness of all collected water samples were varied between $81.7 \mathrm{mg} / \mathrm{L}$ to $188 \mathrm{mg} / \mathrm{L}$ (Table 1). From the observation it is seen that the hardness level was suitable for fish production and environment.

\section{Turbidity}

Turbidity in natural water arises due to the presence of suspended matter such as clay, slit, organic matter, phytoplankton, decomposed dyeing agents, and other microscopic organisms. Actually, turbidity refers to the expression of optical property (Tyndall effect) in which the scattering of light occurs due to suspended particles present in water. The magnitude of scattering of light depends upon the size, shape, and refractive index of such particles Turbidity of all collected water samples was varied between 14.9 NTU to 216 NTU (Table 1), so, from the observation, it is seen that the turbidity level was not suitable for fish production and environment.

\section{Conclusions}

The study show that the eight points in the Buriganga River water is high in BOD, chemical COD, EC, TDS, Salinity, Alkalinity, Turbidity and low in DO which revealed huge environmental health risks and possible ecological disruption of this river. Concerning all the parameters of the study it is clear that the water of Burigangariver is now in a very critical condition.

\section{References}

Ahmed, G.; Uddin, M. K.; Khan, G. M.; Rahman, M. S. and Chowdhury, D. A. 2009. Distribution of trace metal pollutants in surface water system connected to effluent disposal points of Dhaka Export Processing Zone (DEPZ), Bangladesh: A statistical approach, Journal of Nature Science and Sustainable Technology, 3(4): 293-304.

APHA. 1976. Standard methods for the examination of water and wastewater $\left(14^{\text {th }} \mathrm{ed}\right)$. American Public Health Association, Washington 1193.

APHA. 1998. Standard Methods for the Examination of Water and Waste water. 22th ed. Published by APHA, American Water Works Association, and Water Environment Federation.

Chindah, A. C.; Braide, A. S. and Sibeudu, O. C. 2004. Distributions of hydrocarbons and heavy metals in sediments and a crustacean (shrimpsPenaeusnotialis) from the bonny/ new calabar river estuary, Niger Delta. Ajeam-Ragee, 9, pp. 114

Dara, S. S. 2002. A Textbook of Environmental Chemistry and Pollution Control. (S. Chand and Company Limited, New Delhi), pp 24-30.

Das, B. 1997. Fisheries resource management. (Published by Bangla Academy, Dhaka, Bangladesh), pp 153-155.

De, A. K. 2000. Environmental Chemistry. $4^{\text {th }}$ Ed. (New Age International P. limited, New Delhi), pp 2-4.

DOE. (Department of Environment). 2004. A Compilation of Environmental Laws of Bangladesh.

DoE. (Department of Environment). 2005. Government of the people's Republic of Bangladesh, Ministry of Environment and Forest, Department of Environment

Ganeshalingam, S.; Jeyadevan, J. P. and Navaratnarajah, K. 2012. Physicochemical Analysis of Pond Water Samples from Selected Areas in ValukkaiAru Drainage Channel, Jaffna, Sri Lanka. 2(1\&2): 12-23.

Gupta, P. K. 2005. Methods in Environmental Analysis: water, soil and air. (Agrobios. India, Jodhpur), pp 13-73.

Haque, S.; Yasmin, H. and Rahman, M. H. 2002. Environmental Pollution in Bangladesh, Earth Community Organization (ECO).

Islam, M. S.; Mahmud, M. S.; Chowdhury, N. and Shamsad, S. Z. K. M. 2009. Water and sediment anality of Fay"s Lake, Chittagong, Dhaka Univ. J. Bio. Sci., 18(2):147-158

Islam, S. M. N.; Rahman, S. H.; Rahman, M. M.; Adyel, T. M.; Yesmin, R. A.; Ahmed, M. S. and Kaiser, N. 2011 Excessive turbidity removal from textile effluents using electrocoagulation (EC) 
technique, Journal of Scientific Research, 3(3): 557-568.

Islam, M. S.; Uddin, M. K.; Tareq, M. S. M.; Shammi, M.; Kamal, A. K. I.; Sugano, T.; Kurasaki, M.; Saito, T.; Tanaka, S. and Kuramitz, H. 2015. Alteration of water pollution level with the seasonal changes in mean daily discharge in three main rivers around Dhaka, Bangladesh. Environments, 2(3): 280-294

Kabir, E. S.; Kabir, M.; Alam, M. S.; Mia, M. C.; Chowdhury, D. A.; Sultana, M. S. and Rahman, M. S. 2002. Assessment of effluent Quality of Dhaka Export Processing Zone with Special Emphasis to that of the Textile and Dyeing Industries. Jahangirnagar University Journal of Science, 25: 137-145.

Mowka and Edmund. 1988. Understanding factors that Affect $\mathrm{P}^{\mathrm{H}}$, \&Guide to Alkalinity and $\mathrm{P}^{\mathrm{H}}$ control. sea scope. Aquarium systems, 5.

Nemerow, N. L. 1978. Industrial Water Pollution: origins, characteristics and Treatment. Addison Wesley, Reading, Massachusetts, p 738

Rahman, A. A. T. M. 2004. Present status of surface and groundwater condition in Dhaka city, Water Resources Management and Development in Dhaka City. (Geothe-institute publishers, Dhaka, Bangladesh), pp 56-66. 